\title{
Fighting by Betta splendens: Effects on aggressive displaying by conspecifics
}

RONALD BAENNINGER TEMPLE UNIVERSITY

Siamese fighting fish displayed less frequently to mirror images while in water which two conspecifics had just fought in than while in fresh water. Increased acidity of water was noted after two fish had fought in it. The amount of displaying during successive pair encounters decreased, and consistent differences between individuals were found in display frequency.

Suppression of aggressive displays to real opponents or mirror images has occurred in Siamese fighting fish (Bet ta splendens) when certain chemical substances are present in their water. LSD-25 (Abrahamson \& Evans, 1954), reserpine, chlorpromazine (Walaszek \& Abood, 1956), diethylamine HC1 (Thor, Weisman, \& Boshka, 1967), adrenalin and noradrenalin (Baenninger, in press) all reduce the frequency and/or vigor of displays.

In many species of fish substances released by injured conspecifics cause alarm reactions. Von Frisch (1941) found that minnows would school more compactly and flee when as little as $0.002 \mathrm{mg}$ of fish skin (about 0.01 $\mathrm{mm}^{2}$ ) was present in 14 liters of water; he referred to the class of released substances as Schreckstoff or "fear substance." Pfeiffer (1963) reported that many specles from several families of the order Ostariophysii (cypriniform fish) showed this alarm reaction. Among these species were two from the family Anabantidae, of which $B$. splendens is also a member.

Does a fight between two Siamese fighting fish result in the release into surrounding water of substances which suppress aggressive displays by combatants or by subsequent occupants of that water? An answer to this question was sought in the experiment reported here.

\section{Method}

Subjects and maintenance conditions. Twenty-eight adult male Siamese fighting físh served as Ss. All were of approximately equal size. The Ss were housed in 0.5 liter glass aquaria with opaque dividers between them, and were fed brine shrimp daily. Observations were made in 1 liter glass aquaria surrounded by an internally-lighted opaque box containing a viewing hole.

Procedure. All Ss were observed while in fresh water, and while in water which two conspecific fish had just fought in. Fourteen Ss saw mirrors first in fresh water and, one week later, in "fight water." The remaining $14 \mathrm{Ss}$ received the reverse order of presentation. All Ss were observed for $15 \mathrm{~min}$ before the mirror was presented to them for a 15 min observation.

On the day after each mirror encounter, each $\mathrm{S}$ met one other $\mathrm{S}$ in a single pair encounter. Seventeen Ss met in four pair encounters at one-week intervals, against two different opponents. The remaining $11 \mathrm{Ss}$ met in only two pair encounters, i.e., those following mirror encounters. Pair encounters lasted at least $15 \mathrm{~min}$, but were continued until fins or skin was torn on at least one combatant.

In both mirror and pair encounters, the number of extensions of Ss' gill membranes was the dependent variable measured. Ejection of fecal boli was also noted; in pair encounters, establishment of dominance-submission relationships was noted. A S was considered dominant if he successfully caused his opponent to avoid him on twenty successive occasions during the encounter, without ever avoiding the opponent's approach.

\section{Results}

The Ss displayed to mirror images less frequently when in water which had just been fought in by two other fish than in fresh water (Wilcoxon signed rank test, $z=3.64, p<.001$ ). No difference in the frequency of defecation was noted, nor in the length of time during which Ss remained pale with horizontal or vertical dark bands. Only one S displayed once in "fight water" before the mirror was presented; no $S$ ever displayed in fresh water before the mirror appeared.

Readings of the $\mathrm{pH}$ of water clearly indicated that "fight water" ( $\mathrm{pH}=7.80$ ) was more acid than fresh water in which two Ss had merely spent $15 \mathrm{~min}$ without fighting $(\mathrm{pH}=7.91)$, and was also more acid than fresh water (pH = 7.94). Six separate $\mathrm{pH}$ measurements of each type of water showed no overlap of the threedistributions of pH values. Thus, fighting by fish changed the water more than mere presence in the water, and this change apparently suppressed mirror displaying by the next inhabitant of the water. Slight increases in acidity of water can occur in numerous ways, and further experimentation is necessary to isolate the precise chemical changes which occur in water as a consequence of fighting.

Suppression appeared to be rather uniform across all subjects, as Indicated by a significant correlation (Spearman, rank order) between encounters in fresh water and those in "fight" water $\left(r_{s}=0.62, p<.001\right)$. Thus, Ss did not tend to show differential suppression of displaying.

The 17 Ss which met in four pair encounters against live opponents showed a decreasing amount of displaying in successive encounters (Friedman analysis of variance, $x_{r}^{2}=17, d f=3, p<.001$ ). This downward trend replicates a previous finding (Baenninger, in press). Five of these Ss were consistently dominant or sub- 
missive in at least two successive encounters. The three Ss who were consistently submissive in pair encounters against different opponents did not display at all in these encounters, while the two Ss who were consistently dominant displayed frequently but not more than others who failed to reach the dominance criterion. Thus, although social status was defined by chasing or avoiding, while displaying was defined by membrane extensions, the two measures are probably not completely independent.

Regardless of status, there were consistent differences between Ss in the number of displays performed in the four pair encounters. (Friedman analysis of variance, $\left.\chi_{r}^{2}=50, d f=16, p<.001\right)$. Since two different partners were met alternately by each $\mathrm{S}$, these consistencies reflect consistency of the $S$ rather than consistent environmental factors.

It was not possible to compare the amounts of displaying to mirror images and displaying to live opponents in pair encounters, since the latter were continued for longer than 15 min in those cases where no fins were torn in $15 \mathrm{~min}$. Where comparisons were possible no significant difference was found in number of displays. However, Baenninger (1966) found that fighting fish spent more time viewing mirror images than viewing live conspecifics in a choice situation.

\section{Discussion}

It seems clear that an endogenously produced chemical substance is part of a mechanism by which one pair of fish may suppress aggressive displaying by a subsequent inhabitant of that water. Pfeiffer (1963) emphasizes that substances responsible for "alarm reactions" in Ostariophysii are not actively secreted but are released from torn external skin due to mechanical injury. The exact nature of this "alarm reaction" has not been rigorously defined by von Frisch or his students, but it generally seems to involve fleeing and behavior which is called "fright" (Pfeiffer, 1963). In the present work a more precise and objectively defined response has been studied, with results which seem to support the naturalistic observations. Suppression of aggressive displaying may be due to "fright," or it may not. It was not possible to observe any fleeing in the present experiment due to the small size of the testing apparatus. It is known from other work, however, (Baenninger, in press) that submissive Siamese fighting fish do show complete suppression of displaying in the presence of dominant fish.

In observations of group encounters among B. splendens, attacks by a third fish on two fish locked in combat have never been observed in my laboratory, nor do noncombatants display to the fighting pair. It seems possible that aggressive behavior of all non-combatants may be suppressed by chemical means as combatants proceed to tear each other's fins. Since multiple fights could be potentially more damaging to males than pair fights there would seem to be some benefit to the species in possessing mechanisms to inhibit multiple fights.

\section{References}

ABRAHAMSON, H. A., \& EVANS, L. T. Lysergic acid diethylamide (LSD-25): II. Psychological effects on the Siamese fighting fish. Science, 1954, 120, 990-991.

BAENNINGER, R. Catechol amines and social relations in Siamese fighting fish. Animal Behaviour, in press.

BAENNINGER, R. Waning of aggressive motivation in Betta splendens. Psychon. Sci., 1966, 4, 241-242.

FRISCH, K. von. Uber einen Schreckstoff der Fischhaut und seine biologische Bedeutung. Z. vergl. Physiol., 1941, 29, 46-145.

PFEIFFER, W. Alarm substances. Experientia, 1963, 19, 113-123. THOR, D. H., WEISMAN, M. H., \& BOSHKA, S. C. Chemical suppression of fighting in Siamese fighting fish. Psychon. Sci., 1967, 9, 161-162.

WALASZEK, E. J., \& ABOOD, L. G. Effect of tranquillizing drugs on fighting response of Siamese fighting fish. Science, 1956, 124, 440441.

Notes

1. This research was supported in part by funds from the Bolton Fund of the Psychology Department, Temple University.

2. The assistance of Mark Paul and Risetta Dietz is gratefully acknowledged. 